\title{
OBSERVATION INTERFEROMETRIQUE A I69 MC/S DES CENTRES $R$, SOURCES DES ORAGES DE BRUIT
}

\author{
YVETTE AVIGNON, A. BOISCHOT, ET P. SIMON \\ Observatoire de Meudon, Meudon (Seine-et-Oise), France
}

L'interféromètre a ses lobes principaux sensiblement parallèles au plan méridien [1]. Ils ont une largeur de 3'.8 et sont distants les uns des autres de 2 degrés. La détermination de l'heure et de la durée du passage des

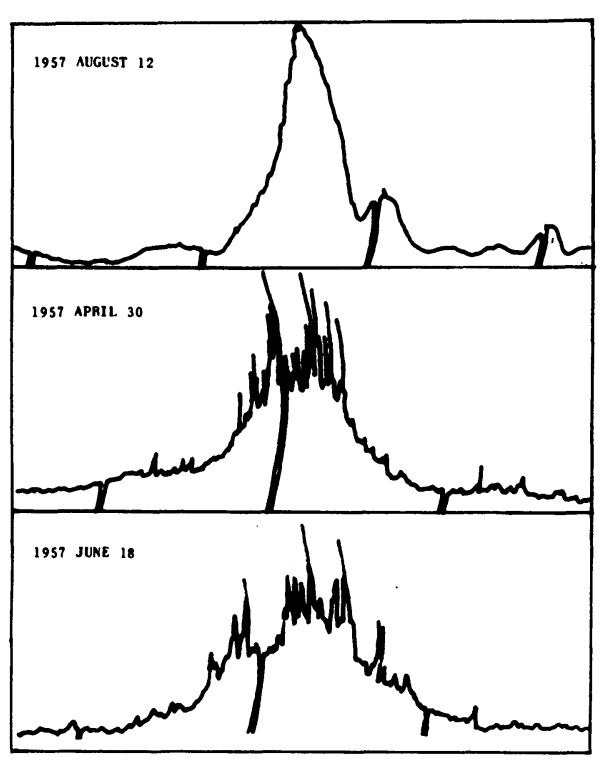

Fig. 1. Centres $R$ observés à $169 \mathrm{Mc} / \mathrm{s}$ avec un lobe de $3: 8$. Les marques de temps se font toutes les minutes. plus forte raison, d'un jour a l'autre. Ils sont de diamètre très variable et s'observent surtout dans la partie centrale du disque.

\section{DIRECTIVITE DE L'EMISSION}

A partir de la distribution des taches optiques sur le disque on peut déduire expérimentalement la distribution que devraient avoir les centres $R$ si l'émission ne présentait aucun effet de directivité. C'est ce que nous avons fait en supposant une altitude moyenne de $0.5 R_{\odot}$ pour les centres $R$ (Fig. 2). L'observation des centres $R$ donne en réalité une distribution qui s'en écarte 


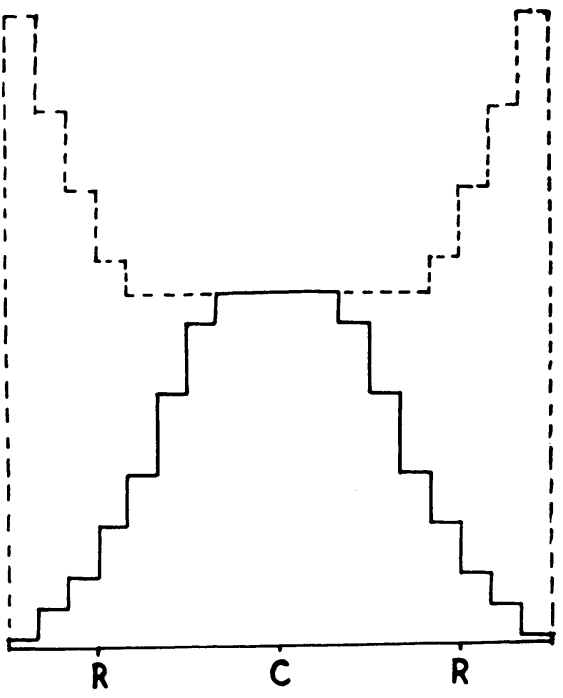

FIg. 2. Comparaison de la distribution des centres $R(-)$ avec celle obtenue à partir de centres optiques (-- -).

notablement. On peut en déduire (Fig. 3) un effet moyen de directivité qui réduit de 50 pour cent le nombre des centres $R$ observés à $0.75 R_{\odot}$ du centre du disque, soit dans l'hypothèse d'une altitude de $0.5 R_{\odot}$ pour une distance de \pm 30 degrés du méridien central. L'étude des densités de flux des centres $R$ en fonction de leur position (Fig. 4) permet de préciser cet effet: on voit que les densités les plus élevées sont au voisinage du centre du disque, alors que les densités observées sur le limbe sont toujours parmi les plus faibles: on peut en déduire que les centres $R$ les plus forts sont certainement directifs. L'étude de la distribution des diamètres appa-

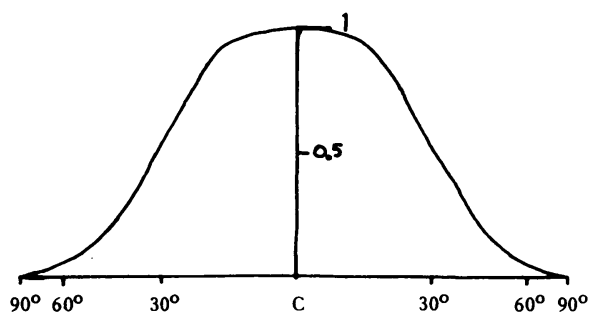

FIG. 3. Diagramme de directivité des centres $R$.

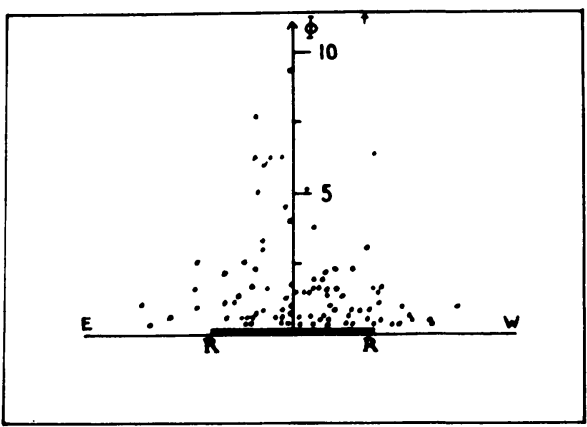

Fig. 4. Densité de flux des centres $R$ en fonction de leur position.

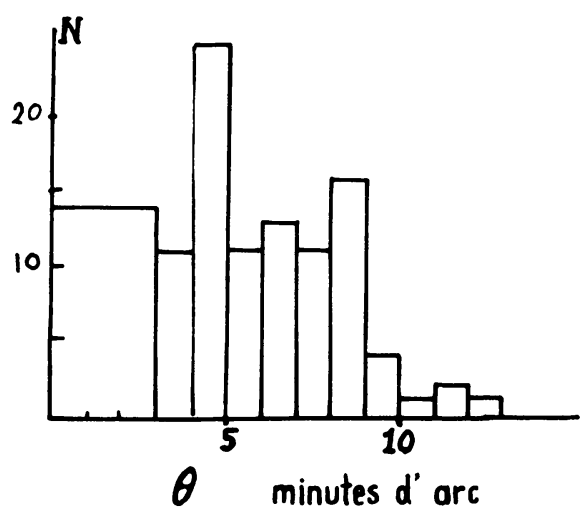

FIG. 5. Distribution des diamètres apparents des centres $R$.

rents montre qu'ils se répartissent de façon sensiblement uniforme entre 1 et 9 minutes d'arc (Fig. 5), certains d'entre eux étant certainement d'un diamètre inférieur à 1 minute d'arc. Leur répartition sur le disque montre que les centres les plus étroits ( $<3$ minutes d'arc) sont proportionnellement plus nombreux sur le limbe qu'au centre du disque. D'ailleurs on observe pratiquement peu de centres larges sur les bords du disque. 

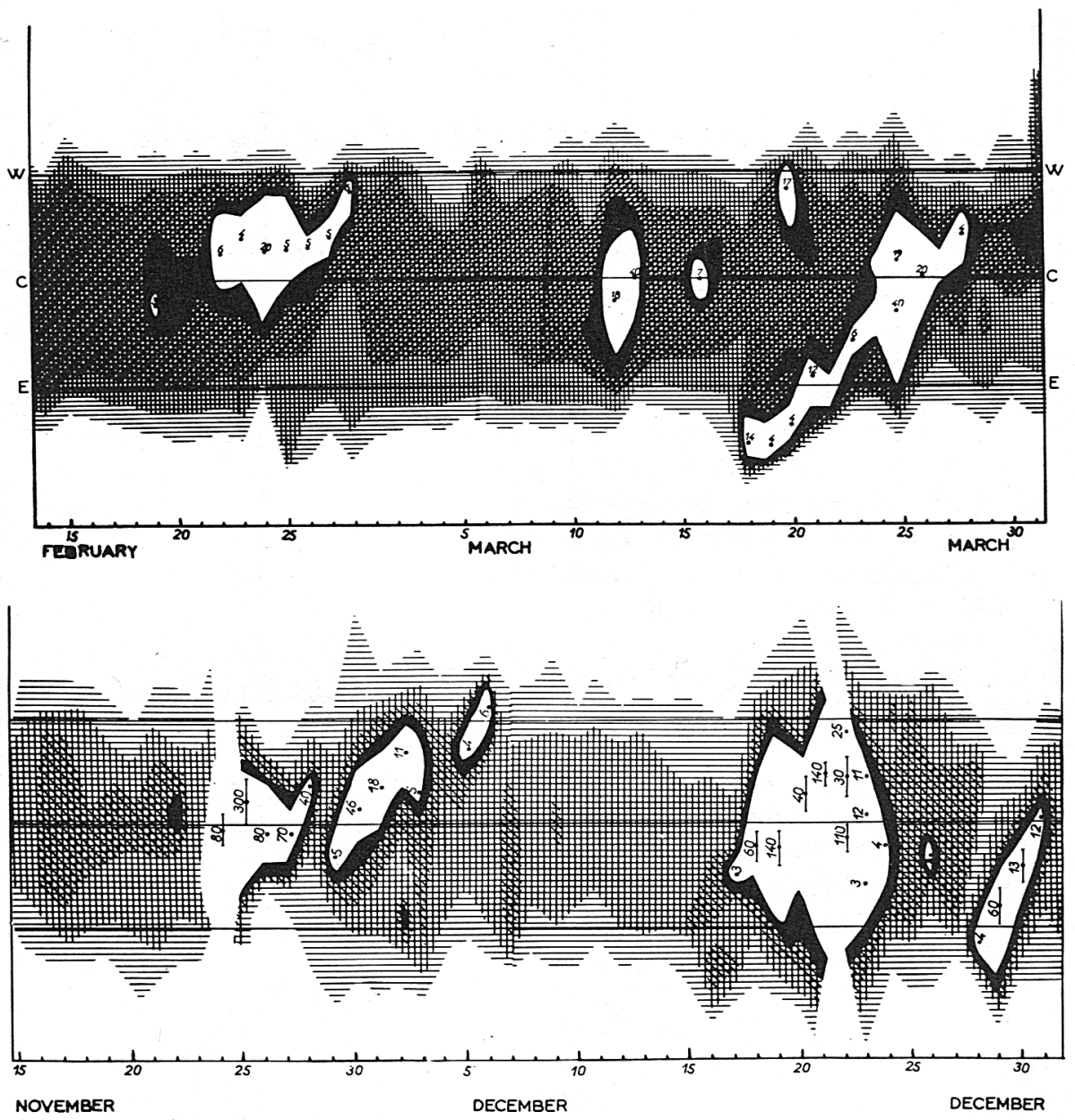

Fig. 6. Diagrammes d'évolution des centres d'activité à $169 \mathrm{Mc} / \mathrm{s}$. Les lettres $C, W, E$ indiquent les positions respectivement du centre et des bords ouest et est du soleil optique. Les chiffres donnent le flux, en unité arbitraire, des centres $R$ dont la position est notée par un point.

\section{ALTITUDE DE LA REGION EMISSIVE}

On pourrait la mesurer en admettant que les centres $R$ sont "au-dessus" des centres d'activité optique, le centre $R$ étant sur le prolongement du rayon solaire passant par le centre optique. On a pu vérifier que cette hypothèse n'est pas satisfaite.

On peut aussi admettre que le soleil et sa couronne tournent comme un corps solide : la vitesse apparente de rotation des centres $R$ permettrait alors de fixer leur altitude. Mais quand le même centre est suivi pendant trois jours ou plus on s'aperçoit que cette hypothèse n'est pas non plus vérifiée: 
les positions des centres $R$ varient soit en altitude, soit en longitude d'un jour à l'autre.

Il reste les observations des centres $R$ sur le limbe. Expérimentalement, c'est la mesure la plus facile: elle donne seulement des limites inférieures de l'altitude qui sont variables d'une tache à l'autre entre 0.3 et $1 R_{\odot}$. Il faut remarquer que ces valeurs sont les valeurs mesurées sans tenir compte d'une effet de réfraction possible dans la couronne.

Dans l'état actuel des observations, cette étude montre surtout l'absence d'une liaison géométrique durable et simple entre centres optiques et centres $R$. Il faut cependant noter qu'aucun mouvement n'a pu être mis en évidence pendant la durée d'une observation, peut-être en raison de sa faible vitesse.

\section{EVOLUTION DES CENTRES " $R$ "}

Pour suivre cette évolution, on porte, jour après jour, la distribution des intensités observées en fonction de leur distance au centre du disque. On obtient des diagrammes (Fig. 6) qui sont publiés dans le Quarterly Bulletin on Solar Activity. Les isophotes ont été choisies arbitrairement pour rendre compte des phénomènes les plus importants correspondant aux centres $R$ sans laisser apparaître ceux de faible amplitude qui existent aussi.

On notera tout d'abord qu'il est très rare qu'un même centre persiste plus de 4 à 5 jours, quel que soit son point d'apparition sur le disque. Ceci distingue nettement les centres $R$ des centres décimétriques et centimétriques. C'est sans doute pour cette raison que l'on n'observe pas de récurrence à 27 jours des centres $R$.

On remarquera aussi qu'il existe des périodes d'activité intense correspondant à l'apparition simultanée de plusieurs centres $R$ à des longitudes solaires très différentes. La plupart du temps ces centres disparaissent aussi simultanément. Cependant l'interféromètre montre que généralement leurs caractéristiques sont différentes les unes des autres.

On voit aussi que, lorsqu'il existe un seul centre $R$ sur le disque, il "tourne" souvent très irrégulièrement et l'on serait tenté de le rattacher successivement à plusieurs centres optiques.

\section{REFERENCES}

[1] Blum, E. J., Boischot A., et Ginat M. Ann. Astrophys. 20, 155, 1957.

[2] Boischot A. Thèse, à paraître Ann. Astrophys.

\section{Discussion}

Denisse: We have determined with the $169-\mathrm{Mc} / \mathrm{s}$ interferometer the origin of bursts of type $I$. The sources of bursts always coincide with the source of the continuum when these two phenomena co-exist. The diameter of certain sources is less than one minute of arc, and definitely smaller than the 6 minutes quoted in the paper. 
Ryle: The difference in the results may be due to the difference in wavelength; at $3.7 \mathrm{~m}$ the scattering produced by the corona will be above four times that at $1.7 \mathrm{~m}$. In 1950 we made some similar observations at Cambridge in an attempt to find the height of the emitting source at a wavelength of 1.4 meters. On many occasions we found a steady variation of the position of the source accompanying the solar rotation, but the deduced heights showed a large scatter, sometimes being below the photosphere! We concluded that the lateral gradients of electron density in the corona around sunspots were probably responsible for refraction effects which made it difficult to use the method.

Denisse : It is not possible to make corrections for refraction, for the radio centers do not rotate regularly; their positions change from one day to the next, and their altitudes are not known. When one observes the radio centers on the limb (4 cases in two years and always on the east limb) one can determine an apparent minimum altitude; in these few cases no effect of refraction has been observed.

Pawsey: The explanation given by Ryle for the greater size at the lower frequency (owing to greater scattering) is probably correct. It is supported by Wild's 1957 observations of a progressive increase in size with decreasing frequency over the range 40 to $80 \mathrm{Mc} / \mathrm{s}$ for both type I and type III bursts. 